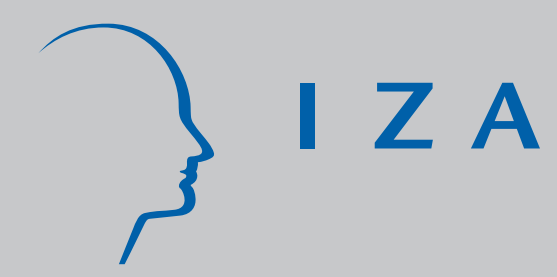

IZA DP No. 985

When Are 'Female' Occupations Paying More?

Štepán J uraj da

Heike Harmgart

J anuary 2004 


\title{
When Are 'Female' Occupations Paying More?
}

\author{
Štěpán Jurajda \\ CERGE-EI, CEPR \\ WDI and IZA Bonn
}

Heike Harmgart

Humboldt University, Berlin

\author{
Discussion Paper No. 985 \\ January 2004
}

\author{
IZA \\ P.O. Box 7240 \\ D-53072 Bonn \\ Germany \\ Tel.: +49-228-3894-0 \\ Fax: +49-228-3894-210 \\ Email: iza@iza.org
}

This Discussion Paper is issued within the framework of IZA's research area Labor Markets in Transition Countries. Any opinions expressed here are those of the author(s) and not those of the institute. Research disseminated by IZA may include views on policy, but the institute itself takes no institutional policy positions.

The Institute for the Study of Labor (IZA) in Bonn is a local and virtual international research center and a place of communication between science, politics and business. IZA is an independent, nonprofit limited liability company (Gesellschaft mit beschränkter Haftung) supported by Deutsche Post World Net. The center is associated with the University of Bonn and offers a stimulating research environment through its research networks, research support, and visitors and doctoral programs. IZA engages in (i) original and internationally competitive research in all fields of labor economics, (ii) development of policy concepts, and (iii) dissemination of research results and concepts to the interested public. The current research program deals with (1) mobility and flexibility of labor, (2) internationalization of labor markets, (3) welfare state and labor market, (4) labor markets in transition countries, (5) the future of labor, (6) evaluation of labor market policies and projects and (7) general labor economics.

IZA Discussion Papers often represent preliminary work and are circulated to encourage discussion. Citation of such a paper should account for its provisional character. A revised version may be available on the IZA website (www.iza.org) or directly from the author. 
IZA Discussion Paper No. 985

January 2004

\section{ABSTRACT \\ When Are 'Female' Occupations Paying More?*}

We compare the importance of occupational gender segregation for the gender wage gap in East and West Germany in 1995 using a sample of social-security wage records of full-time workers. East Germany, which features a somewhat higher degree of occupational segregation, has a gender wage gap on the order of one fifth of the West German gap. Segregation is not related to the West German wage gap, but in East Germany, wages of both men and women are higher in predominantly female occupations. East German female employees apparently have better observable and unobservable characteristics than their male colleagues. These findings are in contrast to a large U.S. literature, but are consistent with the imposition of high wage levels in East Germany at the outset of reforms and the selection of only high-skill women into employment. Finally, conditioning on unobservable labor quality differences using the longitudinal dimension of the data, there is a negligible impact of segregation in both parts of Germany.

JEL Classification: J16, J21, J71

Keywords: occupational segregation, gender wage gap

Corresponding author:

Štěpán Jurajda

CERGE-EI

Politických vězñů 7

Prague

Czech Republic

Email: stepan.jurajda@cerge-ei.cz

\footnotetext{
* The authors would like to thank Michael Burda, Randall Filer, Andrea Ichino, Dean Jolliffe, Joep Konings, and Rudolf Winter-Ebmer for helpful comments. Harmgart would like to thank the Institute for Economic Theory II at the Humboldt University Berlin for letting her use the IAB data. This research was supported by Volkswagen Stiftung through grant no. II/75 828.
} 


\section{Introduction}

One of the most clearly established facts in the literature on the gender wage gap is that there are large and persistent differences in the share of female workers across occupations and that wages of both men and women decrease with the presence of females in their occupation. Concentration of women in low paying occupations is therefore a major source of the gender wage gap.

There are three main possible explanations for why 'female' occupations pay less. First, women may face discriminatory hiring, firing, and promotion practices, which prevent them from working in high-wage occupations. Second, 'female' occupations may offer costly non-wage characteristics (e.g., flexibility of work hours); women are then more likely to accept lower wages because they prefer such occupational attributes. Third, workers employed in 'female' occupations may have lower skills (both observed and/or unobserved).

Researchers analyzing the relationship between individual wages and the 'femaleness' of occupations have therefore recently taken into account not only observed productive characteristics of workers, but also occupational attributes and unmeasured worker skills and occupational preferences. In the U.S. and Canada, controlling for these additional factors substantially reduces the wage penalty to female jobs (Macpherson and Hirsh, 1995; Baker and Fortin, 2001).

Another line of research uses cross-country differences in labor-market institutions and wage structures to study the sources of the gender wage gap (Blau and Kahn, 2003) and the penalty to working in predominantly female occupations (Baker and Fortin, 1999). In this paper, we extend the cross-country literature by investigating the effect of occupational gender composition on wages in East and West Germany in 1995. West Germany represents a regulated European labor market with a stable, compressed wage structure and low female employment rates. On the other hand, East Germany has been subject to the most radical pro-market reform among all post-communist economies as the German unification brought about instant implementation of western-style labor market institutions. The two parts of Germany therefore offer three interesting comparisons. First, 
one can contrast the West German results to findings available for the U.S. ${ }^{1}$ Second, the EastWest German comparison can help distinguish the effect of institutions from those of different labor market histories. Third, the East German evidence can be compared to findings from other transition economies in order to shed light on the effects of radical pro-market reforms. ${ }^{2}$

The existing research on occupational gender composition and wages in post-communist countries finds that occupational segregation is an important source of the overall gender wage gap (see Ogloblin, 1999, for evidence on Russia, and Jurajda, 2003, for results from the Czech and Slovak Republics). However, East Germany offers a particularly interesting case for study because the German unification led to the imposition of high wage levels early on in the transition process. Enterprise restructuring was radical as employment dropped by 35\% between 1989 and 1992 (Burda and Hunt, 2001). This contrasts with a more gradual reform process in other transition countries, where wages decreased early on in transition. These different reform paths may have affected women differently. While the gender wage gap has been stable or growing in most post-communist countries (Newell and Reilly, 2000; Brainerd, 2000), the East German gap has decreased since unification. Hunt (2002) suggests that this has been in large part due to low-earning women selectively dropping out of the labor force. However, no evidence exists on the extent and the wage effects of gender segregation in East Germany. Yet, such evidence would be important for evaluating the early introduction of western-type anti-discrimination policies in East Germany, which occurred as part of the German unification. ${ }^{3}$

In this paper, we therefore reduce the gap in the empirical literature by first asking whether East German occupations are relatively more or less segregated in terms of gender compared to those in West Germany. Second, we provide descriptive evidence on pay differences between men

\footnotetext{
${ }^{1}$ See Dolado et al. (2002) for a comparison of the U.S. and European female employment rates and Freeman and Schettkat (2000) and Beaudry and Green (2003) for U.S.-German wage structure comparisons.

${ }^{2}$ See Burda and Hunt (2001) or Riphahn et al. (2001) for detailed analyses of East German reforms.

${ }^{3}$ German law provides the typical "western" set of anti-discrimination clauses. Apart from the constitutional guarantee of equal rights, there are clauses requiring equal pay and prohibiting unequal hiring, firing and promotion practices (that is prohibiting discriminatory segregation). There have been a variety of court cases and respective rulings enforcing these laws.
} 
and women. Third, we investigate the effects of workplace segregation on the gender wage gap in both parts of Germany.

We employ a large representative administrative sample of workers from 1995 — the so called IAB employment subsample, which consists of wage records drawn from the German Social Security database. Due to a lack of information on hours worked we focus on full-time workers. In a subset of our analysis, we form a matched employer-employee data set, which enables the study of withinestablishment wage differences. The wage structure is described using logarithmic wage regressions conditioning on worker and firm characteristics as well as on the fraction of women within a given occupation. We focus on the cross-sectional relationship between wages and segregation, but we also attempt to come closer to a causal effect of segregation on wages by conditioning on unobservable worker skills and occupational preferences. Specifically, we use a panel of workers employed in 1992 and 1995, the earliest and latest years for which the (East German) data are available, to remove all time-constant worker characteristics. The estimated coefficients are then used together with the mean differences in explanatory variables by gender to quantify the part of the wage gap explained by gender segregation.

Our analysis uncovers intriguing East-West differences. East Germany, which features a somewhat higher degree of occupational segregation, has a much smaller gender wage gap. The West German wage gap is substantial, both across all workers and within jobs (occupation-firm cells), but there is almost no difference between the median wages of East German full-time male and female workers. Yet, there are significant East German gender wage gaps within jobs. Our regression analysis reconciles these pieces of descriptive evidence: We find little support for the existence of a wage penalty to 'female' jobs in West Germany. Occupational segregation therefore does not explain the higher wage gap in West Germany. The significant within-job wage gaps in East Germany do not appear at the aggregate level because more 'female' occupations actually offer higher wages, in striking contrast to findings from the U.S. as well as from transition countries. We rely on 
indirect evidence, both within- and cross-country, to offer an explanation for this arresting finding; the explanation is related to the radical reform path of East Germany. Finally, conditioning on unobservable labor quality, the wage impact of gender segregation is small in both parts of Germany.

\section{Background}

\subsection{Occupational Gender Segregation and Wage Gap}

Occupational segregation is the subject of extensive research. It is more pronounced in the EU countries compared to the U.S. for low-educated workers (Dolado et al., 2002). There is widespread evidence that wages of both male and female workers are lower when they are employed in predominantly female occupations; see Kilingsworth (1990), Groshen (1991) or Bayard et al. (in press) for U.S. evidence, and Baker and Fortin (2001) for results from Canada. While occupational segregation is often attributed to discriminatory employer practices, Filer (1986) and Macpherson and Hirsh (1995) are among the researchers who suggest that it is in large part due to gender differences in preferences for occupational characteristics or to sorting on unobserved labor quality. ${ }^{4}$

The suggested mechanisms giving rise to the observed negative correlations between the female share of an occupation's workforce and the respective wages of men and women often differ by gender. For example, if women are discouraged from entering high-wage occupations by discriminatory barriers, then only women with very high (possibly unobservable) labor quality will be able to enter the typically 'male' occupations. The fraction of female workforce then becomes an index of labor quality and only low-quality men will sort themselves into the more 'female' occupations.

Another strand of the literature relies on cross-country research design to analyze the importance of labor market institutions for employment patterns by gender (Bertola, et. al, 2002), the gender wage gap (Blau and Kahn, 2003) or the occupational gender segregation (Baker and Fortin, 1999). Comparing the United States and Canada, Baker and Fortin (1999) find the wage penalty to jobs principally employing female workers to be larger in the U.S. and link this finding to a low U.S.

\footnotetext{
${ }^{4}$ For a theoretical model where workers of complementary skills are grouped together see Kremer (1993).
} 
female unionization rate and low wages in certain public-goods-sector jobs. However, there are no detailed studies comparing occupational segregation wage effects in the regulated European labor markets to those found in the Anglo-Saxon economies.

\subsection{Female Wages in Transition}

There is a wealth of research analyzing the evolution of the gender wage gap during early promarket reforms when wage dispersion increased dramatically and when labor force participation rates decreased from the artificially high levels of the communist era. ${ }^{5}$ A typical finding from these studies is that gender differences in observed worker characteristics contribute little towards the significant raw wage gaps between men and women. While the gender wage gap has been quite stable in many transition countries (Newell and Reilly, 2000), it has dropped by about 10 percentage points in East Germany. Hunt (2002) attributes much of this decrease to low-earning women selectively dropping out of the labor force.

The 1990 monetary union between East and West Germany led to a large increase in East German wage level while western trade unions took over the East German wage bargaining system. Drastic restructuring and mass layoffs were accompanied by early retirement policies and other public-assistance programs. Hunt argues that union wage rises have caused the less productive to be laid off and that the decreased child care availability in the eastern lands was not important in the selective layoff process. Today, the East German female employment ratio is comparable to that of West Germany, but the level of its female labor-force participation still remains relatively high. ${ }^{6}$ This has been explained by Bonin and Euwals (2002) as being largely due to the different pro-participation characteristics of the Eastern female workforce, inherited from the communist times of female labor-market emancipation.

\footnotetext{
${ }^{5}$ See, e.g., Brainerd (1998) for Russia or Jolliffe (2001) for Bulgaria. Ogloblin (1999) and Brainerd (2000) provide an analysis of the institutional background to gender under communism.

${ }^{6}$ Using the 1995 Microcensus data, the female (male) employment ratio is $0.36(0.53)$ in West Germany and 0.38 (0.51) in East Germany. The corresponding female (male) labor force participation rate is 0.39 (0.58) in West Germany and 0.48 (0.57) in East Germany.
} 
Out of the many gender wage gap studies of transition economies, only two pay close attention to the issue of gender segregation. Ogloblin (1999) analyzes the Russian Longitudinal Monitoring Survey from 1994-1996 and finds that the gender pay gap cannot be explained by gender differences in education and experience. However, additional conditioning on industry and firm ownership dummies as well as on a class of occupational dummies capturing overwhelmingly "male" and "female" occupations accounts for over $80 \%$ of the Russian wage gap. Jurajda (2003) uses large matched employer-employee data covering medium- and large-firm Czech and Slovak employment in 1998 to suggest that in Central Europe segregation of women into low-paying occupations and firms is responsible for only about one third of the total wage gap.

\section{Data}

The data we use consist of a one-percent random sample of the German Social Security records, perhaps better known as the IAB employment subsample. ${ }^{7}$ The West German data is available from 1975 until 1995 while the East German file spans the 1992-1995 period. The original data consists of various types of social security records (notifications) including the start and end of employment spells. The employment (and wage) information is also updated at the end of each year. The 1995 end-of-year cross-section of employees forms the basis for our analysis. In a subset of our analysis, we also use the panel of workers employed in both 1992 and 1995.

German social security reporting covers virtually all of its enterprise employment. Only civil servants and self-employed workers are excluded from contributions (and the IAB sample). ${ }^{8}$ As of 1995, the social security records cover almost 80 percent of total West German employment and over 86 percent of East German employment.

Besides a number of personal and firm characteristics, including the workers' occupation, the

\footnotetext{
${ }^{7}$ See Bender et al. (2000) for a detailed data description. The data are anonymized and distributed through the Institut für Arbeitsmarkt und Berufsforschung der Bundesanstalt für Arbeit (IAB), the German Institute for Employment Research.

${ }^{8}$ Even though public servants are not included in the IAB data, 10 to 15 percent of social-security employees work in state institutions or non-governmental organizations in health, public administration or education sectors.
} 
data also provide average gross daily wages for each corresponding employment notification. Having only daily wage rates, as opposed to hourly rates, is a major weakness of our study. It may lead us to confound gender differences in hours worked with true wage-rate differentiation; hence, we focus our analysis on full-time employment in order to minimize work time differences. ${ }^{9}$ While wages of part-timers remain outside the scope of our analysis, it is important to acknowledge the potential gender wage discrimination operating through lower wages of typically female part-timers in Germany. ${ }^{10}$

The wage data is censored from above (top coded), which affects approximately 10 (4) percent of the wage records in West (East) Germany for both years. Hence, our descriptive analysis focuses on median wage gaps and we also check for sensitivity to top-coding in our regression analysis. On the other hand, the wage information in the IAB data has an important advantage in that the wage definition is the same across all time periods and firms. The social security administration performs various plausibility checks on the wage data and issues sanctions for misreporting, thereby ensuring high accuracy. The use of administrative records minimizes reporting errors for other variables as well.

The data have another important advantage: Sampling one percent of all social security notifications results in an extensive database. In 1995 the IAB sample includes over 140 thousand end-of-year employment records in West Germany and over 40 thousand such records in East Germany. ${ }^{11}$ The large scale of the data allows us to precisely estimate the gender composition of occupations and to create a matched employer-employee sub-sample. ${ }^{12}$ Having available several workers from the same firm allows us to explore the extent of the gender wage gap within occupa-

\footnotetext{
${ }^{9}$ We check for the gender differences in hours worked using the German Socio-Economic Panel in Section 4.2.

${ }^{10}$ Wolf (2002) shows that hourly wages of West German part-time female workers are lower than wages of women working full time. Since only few male worker are part-timers, this issue is important for overall gender pay differences. In a recent ruling, the German supreme court stated the right for equal hourly payment between part-time and fulltime employment and also made explicit that a company (in this case the German Post AG) used lower payment of its part-time employees as an indirect way of discriminating against its female workers (BVERFG 1. Senat 2. kammer 19.05.1999. 1 BvR 263/98).

${ }^{11}$ The East-West distinction in the IAB data is based on current residence.

${ }^{12}$ We form the matches using the unique establishment number issued by the German Employment Service.
} 
tions within firms. Of course, given that we work with a random sample of workers, we can only match several workers to their employer for large firms.

The estimation-ready data was selected as follows: We start with all end-of-year employment notifications - a simple cross-section of social-security employment for 1995. From this data we omit records for non-Germans, home and part-time workers, and records with missing wage information as well as those notifications for full-time employment with daily wages below 60 German Marks (DM). ${ }^{13}$ (A similar procedure was applied to obtain the 1992 sample which is used together with the 1995 data in our longitudinal analysis.) The 1995 data descriptive characteristics are presented in the first two columns of the top panel of Table 1 . We have available over 180 thousand workers from almost 110 thousand firms. While the average age of full-time social-security employees is comparable across the two parts of Germany, the share of female workers is much higher in East Germany, reflecting in part the higher propensity of males to be self-employed there (see, e.g., Hunt, 2002). East German employees also have higher educational levels while wages are obviously higher in the West.

Next, we check whether the IAB sample is consistent with other data sources on the German labor market. Most analyses of the German wage structure rely on the German Socio-Economic Panel (GSOEP), a relatively small, but rich longitudinal household survey. In the next two columns of Table 1, we therefore compare the basic characteristics of the IAB sample to those of a GSOEP sub-sample selected to mimic the nature of the IAB data. ${ }^{14}$ Comparing the IAB and GSOEP pairs of columns in Table 1 shows that the two sub-samples have a very similar demographic structure. The main difference is in the level of wages, which are higher based on the GSOEP survey responses. ${ }^{15}$

\footnotetext{
${ }^{13}$ Our goal is to minimize the possibility of including a part-time (female) worker in our final sample. The choice of the 60DM cutoff is consistent with the general level of (industry-specific) minimum wages in Germany.

${ }^{14}$ We start with the basic GSOEP sample and drop self-employed, civil servants as well as part-time and very-lowwage workers. We apply the cross-sectional GSOEP weights to generate the reported sample characteristics.

${ }^{15}$ The GSOEP asks respondents about their gross salary from the previous month (earnings before deductions for tax and social security, including overtime payments, but excluding bonuses). To roughly approximate the daily wage, we divide this number by 20 . We are mainly interested in comparing not the wage level, but the gender gaps in daily wages across the two datasets, IAB and GSOEP; see Section 4.2.
} 
On the other hand, we note that the East-West German median wage ratio is the same in both samples at 0.71 . We conclude that our IAB subsample is comparable to the relevant subsample of the GSOEP.

Finally, we note that the Social Security administration uses a three-digit occupational classification. We have available a total of 274 detailed occupation classes. ${ }^{16}$ Inspection of the occupations' size reveals the presence of one outlier: The class of skilled office clerks covers over 12 percent of workers in both East and West Germany and so it forms the largest occupation in the data. ${ }^{17}$ We want to minimize the possibility of meaningful differences in the content of this large occupation and so we interact this occupation with the 15-branch industry indicator (see, e.g., Dolado et al., 2002, for a similar approach).

\section{Analysis}

\subsection{Descriptive Evidence on Segregation}

What are the main features of female employment in our two economies? First, the share of women out of total full-time social-security employment is higher in East Germany at 39 percent compared to 33 percent in West Germany in 1995 (Table 1), likely reflecting the higher male propensity to enter self-employment in the early transition period. A view of occupational segregation by gender is offered in the two graphs of Figure 4.1, where the worker distribution of the share of females within the $274 \mathrm{IAB}$ occupation classes is plotted for both parts of Germany in 1995. For example, in West Germany almost 30\% of all full-time social-security employees work in 3-digit occupations that are entirely staffed by men. The overall pattern of occupational segregation is quite similar across the two parts of Germany. Indeed, the East-West correlation of the share of females at the 3-digit occupation level is high at 0.91 , suggesting strong similarity in the gender composition of

\footnotetext{
${ }^{16}$ These classes do not correspond to the ISCO codes of the International Labor Organization. For use of otherthan-ISCO 3-digit occupational schemes see, e.g., Macpherson and Hirsh (1995).

${ }^{17}$ The second largest occupational class covers less than $4 \%$ of all workers in both East and West Germany; the rest of the size distribution is continuous. The skilled office clerks category, Bürofachkräfte in German, includes secretaries or personal assistants, but not typists (Stenographen, Stenotypisten, Mashienenschreiber, Datentypisten) or support clerical staff (Bürohilfskräfte).
} 

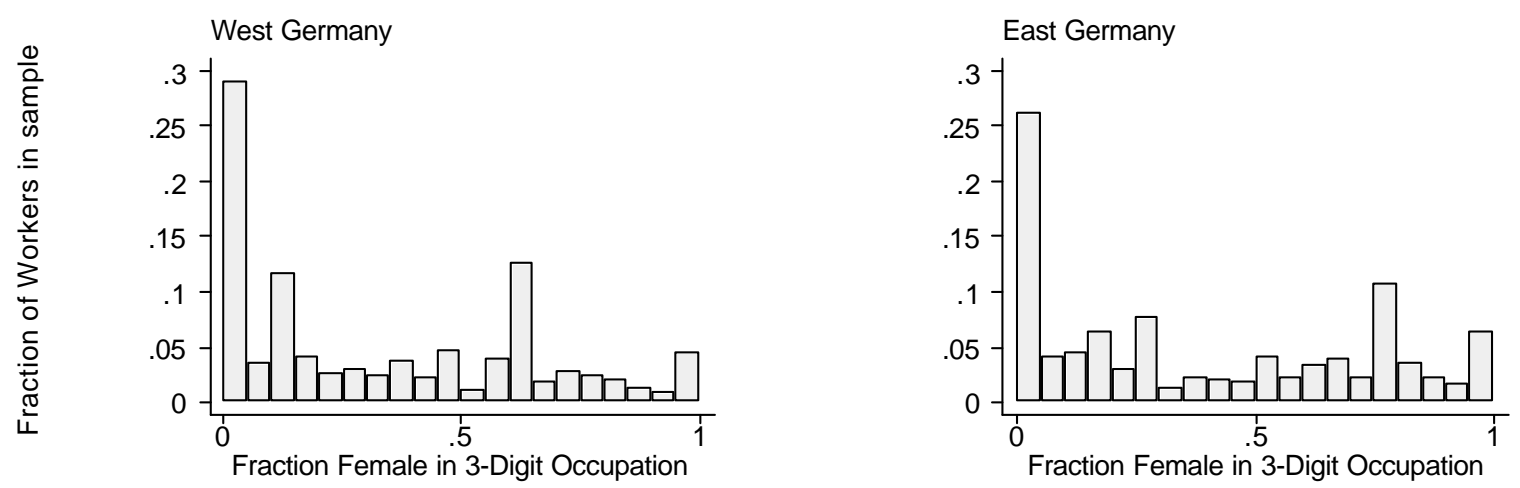

Figure 4.1: Occupational Gender Segregation in Germany in 1995

occupational employment, despite the different history (of labor market practices).

A summarizing measure of occupational gender segregation typically used in the literature is the Duncan and Duncan (1955) segregation index $S$ defined as

$$
S=\frac{1}{2} \sum_{i}\left|m_{i}-f_{i}\right|,
$$

where the subscript $i$ denotes occupation, $m_{i}$ is the proportion of males employed in occupation $i$ and $f_{i}$ is the corresponding fraction of females. The index can be interpreted as reflecting the sum of worker reallocation required to equalize the gender composition of occupations. In 1995, the index takes on the value of 61 percent in West Germany and 65 percent in East Germany, signaling somewhat higher occupational gender segregation there.

In Table 2, we calculate the Duncan index for twelve demographic groups defined by age and education in both parts of Germany. We only report the East-West comparison for groups which form over 2 percent of employment in at least one part of Germany. The group-specific statistics suggest that occupational gender segregation is much more pronounced in the East as compared to the West for young workers. On the other hand, those in the large group of employees over 44 years of age with an apprenticeship degree have virtually identical segregation index and the small group of older Eastern workers with a college degree is much less segregated across occupations compared 
to their Western colleagues. These results suggest that we should investigate the wage-segregation relationship not only for the whole sample of German workers, but also with particular focus on young workers in East Germany.

\subsection{Descriptive Evidence on the Wage Gap}

What is the size of the gender wage gap for full-time social-security employees on the post-unification labor market? We represent the gap using the wage disadvantage of women defined as $1-\overline{w_{f}} / \overline{w_{m}}$, where $\overline{w_{m}}$ stands for the median male wage and $\overline{w_{f}}$ is the corresponding female wage. In 1995, the median unconditional wage gap, expressed in percentage points, is 22 in West Germany but it is - 1 in East Germany (see the second panel of Table 1). We also estimate the mean gender wage gaps, which are larger at 30 percent in West Germany and 6.2 percent in East Germany. ${ }^{18}$

These are striking findings. The Eastern gap is remarkably low: It is only about one fifth the size of the Western gap using the mean wage comparison. Even more striking is the finding based on median wages: A typical East-German full-time female employee is paid slightly more than her male counterpart.

These results call for comparison. We use the 1995 GSOEP data and select a sub-sample mimicking the composition of our IAB data. The resulting wage gaps are reported in the bottom panel of Table $1 .^{19}$ Using the GSOEP self-reported wage measure, we replicate the IAB median wage gap in West Germany and we also confirm that the East German wage gap is very small. The remaining difference of about 4 percentage points in our estimate of the East German median wage

\footnotetext{
${ }^{18}$ The mean is estimated as $E[w]=\operatorname{Pr}\left(w<w^{c}\right) E\left[w \mid w<w^{c}\right]+\operatorname{Pr}\left(w \geq w^{c}\right) w^{c}$, where $w^{c}$ is the top-coded wage value.

${ }^{19}$ The IAB wage measure includes bonuses and fringe benefits, while these are excluded from the GSOEP wage definition. Both the IAB and GSOEP wages we use in our calculations are not corrected for gender differences in hours worked. Information on hours worked is available in GSOEP. Constraining the GSOEP sample to mimic the IAB employment (full-time workers, no civil servants or self-employed) and dropping observations with weekly hours below 30 or above 60, gender differences in contractual (actual) hours are in the order of 1 (5) percent in both East and West Germany in both 1992 and 1995. We conclude that (i) the East German wage-rate gap may be even more negative than we report, and (ii) differences in hours worked are unlikely to affect our East-West comparison. Nevertheless, the size of the bias is unclear as Pannenberg (2002) reports that a large fraction of overtime hours is unpaid in West Germany.
} 
gap may be due to sampling error as the East German restricted GSOEP sample consists of only 1425 workers. Further, the mean wage gap in our GSOEP sub-sample is $26 \%$ in West Germany and $7 \%$ in East Germany, quite close to our IAB approximate mean wage gaps. Given the large size and the administrative nature of the wage information in the IAB sample, we feel confident that our results are informative about the wage gap of full-time German social-security workers.

It is natural to ask whether the lack of median wage differences in East Germany corresponds to a perfectly equalized wage setting in which men and women working on the same job are paid equally. A unique advantage of the IAB data is that it allows one to answer this question directly. Using the matched employer employee sub-sample (see Section 3) we can ask about pay differences between men and women working in the same detailed occupation in the same firm - in the same job. The bottom panel of Table 1 compares the overall wage gaps to those based on within-job comparisons. Each entry is the percentage wage disadvantage for females averaged across all job cells where we could match at least one male and one female worker, that is predominantly in large firms. The results imply that median wages of such male and female co-workers differ by about 7 percent in East Germany and by about 15 percent in West Germany. ${ }^{20}$

These are remarkably large within-job wage gaps, especially in the context of the overall differences in male and female wages, even though these are based on a broader sample of all workers and firms. In West Germany, there is a wage gap of almost one sixth among very similar workers of different gender. In part, the job-cell wage gap may be caused by differences in hours worked, but its extent calls for further investigation of potential violations of the equal pay act. The size of the within-job wage gap also suggests that occupational segregation may not be an important source of the relatively large West German overall wage gap. In East Germany, our results thus far suggest the coexistence of a significant gender wage gap within jobs with an almost fully equalized overall

\footnotetext{
${ }^{20}$ The average wage gaps are only slightly higher than the median wage gaps. The averages are taken across all observed job-cell wage-gap observations. Weighting by the size of each observed worker group makes no material difference. The median wage gaps are not sensitive to constraining the analysis to job cells with at least 3 men and 3 women.
} 
wage. A leading potential explanation for such a pattern of wage gaps is that 'female' occupations pay more. We explore this hypothesis below.

\subsection{Accounting for the Wage Gap}

In this section, we account for the sources of the observed wage gaps using logarithmic wage regressions. Specifically, we ask about the explanatory power of (i) worker and firm characteristics, and (ii) occupational segregation. Following the literature (e.g., Groshen, 1991; Macpherson and Hirsh, 1995; or Bayard et al., in press), we capture the effect of gender segregation on wages by conditioning on the 'femaleness' of occupations. 'Femaleness' is measured by the percent of females $(P)$ in a given group of employees. ${ }^{21}$ We therefore estimate logarithmic Least Squares wage regressions of the following form separately for each gender and part of Germany:

$$
\ln w_{i j}=X_{i j}^{\prime} \beta+P_{j} \gamma+\eta_{j}+\epsilon_{i j}, \text { with } i=1, \ldots N_{j}, \text { and } j=1, \ldots, J
$$

Here, $w_{i j}$ denotes the daily wage of the $i$-th worker in the $j$-th occupation, $X_{i j}$ represents the observed worker and firm characteristics, $P_{j}$ is the fraction of female employment in $j$-th occupation, $\eta_{j}$ captures the occupation-specific unobservable attributes, $\epsilon_{i j}$ includes the unobserved workerspecific skills, $J$ denotes the total number of occupations, and $N_{j}$ is the number of workers in the sample employed in the $j$-th occupation.

Equation 1 highlights two important sources of estimation problems. Unfortunately, we are not able to fully control for the first unobservable, the occupation-specific attributes $\eta_{j}$, which may lead to an upward bias in $\gamma$ if women prefer occupations which offer costly attributes (e.g., flexible working hours or lack of physical-strength demands). Secondly, sorting of workers into occupations based on unobserved labor quality is a feature of an important hypothesis in the occupational

\footnotetext{
${ }^{21}$ We estimate the occupation-specific fraction of female workers from within our data. Given the cross-sectional size of the data, this results in precise estimates of occupations' 'femaleness.' In contrast, using our data to estimate the share of women out of a firm's workforce would results in a noisy measure give the low number of workers matched to each firm (Table 1). Also, recall that we use the detailed IAB 3-digit occupational classification. Having a detailed categorization of occupations is important for minimizing the extent of measurement error (bias) to the extent that there are meaningful differences in the content of occupations within broad occupational categories.
} 
segregation literature (see Section 2.1). If the occupational averages of worker unobserved skills $\left(\epsilon_{i j}\right)$ are correlated with the 'femaleness' of occupations $\left(P_{j}\right)$, this would again lead to a biased estimate of $\gamma$. One can remove the time-constant unobservable worker skills by "differencing" observations for the same worker from two time periods. We follow this strategy below, but first, we present a set of traditional cross-sectional estimates.

The possibility of correlated unobservables within occupations also affects statistical inference in our cross-sectional estimation. To provide a conservative basis for inference, we therefore capture occupation-level clustering of unobservables using a panel-data version of the Huber/White variance estimator:

$$
\widehat{V}(\widehat{\delta})=\left(Z^{\prime} Z\right)^{-1}\left(\sum_{j} Z_{j}^{\prime} \widehat{\epsilon}_{j} \widehat{\epsilon}_{j}^{\prime} Z_{j}\right)\left(Z^{\prime} Z\right)^{-1}
$$

where $\delta^{\prime}=\left(\beta^{\prime}, \gamma^{\prime}\right), \widehat{\epsilon}_{j}=\ln w_{j}-Z_{j} \widehat{\delta}$ is the column vector of estimated error terms for workers in the $j$-th occupation, and where $Z_{j}=\left(X_{j}, P_{j}\right)$ is the matrix of regressors rearranged along the occupational dimension.

\subsubsection{Standard Explanations}

The least-squares regression estimates for West and East Germany are presented in Tables 3a and 3b respectively. Columns (1) and (3) list standard specifications conditioning on both worker and firm characteristics but not on occupational segregation measures. Given the absence of actual labor market experience in the data, we choose to include among the regressors the number of children and a marriage indicator together with a quadratic in age. By doing so, we aim to control for the wage effects of (past) maternity leaves to the extent allowed by the data. We also condition on the type of employer by including a set of industry and firm-size dummies. The estimates suggest very similar returns to education across both economies and genders as well as a strong similarity in the estimated industry wage structures.

Next, we use the estimated coefficients to ask about the sources of the gender wage gaps in 
Germany using the Oaxaca-Blinder decomposition. The approach focuses on first moments of wages, relying on the fact that fitted regressions pass through sample means (Oaxaca, 1973). A general form of the mean wage decomposition is as follows:

$$
\overline{\ln w_{m}}-\overline{\ln w_{f}}=\left(\overline{X_{m}}-\overline{X_{f}}\right)^{\prime} \widetilde{\beta}+\left[{\overline{X_{m}}}^{\prime}\left(\widehat{\beta_{m}}-\widetilde{\beta}\right)+{\overline{X_{f}}}^{\prime}\left(\widetilde{\beta}-\widehat{\beta_{f}}\right)\right]
$$

where $f$ denotes females and $m$ denotes males, $\overline{\ln w_{s}}$ is the gender-specific mean of the natural logarithm of hourly wage, $\overline{X_{s}}$ represents the respective vectors of mean values of explanatory variables for men and women with $s \in\{f, m\}$. Finally, $\widehat{\beta_{m}}$ and $\widehat{\beta_{f}}$ are the corresponding vectors of estimated coefficients from gender-specific wage regressions and $\widetilde{\beta}$ represents a counter-factual non-discriminatory wage structure. The first term on the right hand side of equation 3 represents that part of the total logarithmic wage difference which stems from the difference in average observed productive characteristics across gender. The second term originates in the differences in gender-specific coefficients from the non-discriminatory wage structure and is often interpreted as providing an upper limit on potential wage discrimination. There are a number of variants of this method depending on how one approximates the non-discriminatory wage structure; see Oaxaca and Ransom (1994). In line with their recommendation, we use the weighted average of the genderspecific coefficients with weights corresponding to shares of each gender out of all employment (for a similar approach, see, e.g., Macpherson and Hirsh, 1995).

The Oaxaca-Blinder decomposition is presented in Table 4. Summing up the products of average coefficients (column 1 or 3 ) and $X$ differences (column 2 or 4 ) for each part of Germany, we find that gender differences in demographic and firm characteristics account for 7.5 percentage points of the overall gender wage gap in West Germany. In East Germany, however, we find that the gender differences in productive characteristics actually work to women's advantage, reducing the gap which would have been larger if the distribution of $X$ was equalized across men and women. (For qualitatively similar findings from post-communist countries, see Ogloblin, 1999, or Jurajda, 2003.) In particular, we note that East German women have better educational levels than their male 
colleagues and that they are more likely to work in the highly-paid service and public-administration sectors.

\subsubsection{Cross-Sectional Effects of Occupational Segregation}

Our goal is to learn about the importance of occupational segregation for wages. In columns (2) and (4) of Table 3, we therefore introduce an additional regressor to our previous specification, namely the share of female workers in occupation. The demographic and firm coefficients remain stable. The West German occupational segregation coefficients we obtain suggest there is no statistically significant relationship between the 'femaleness' of 3-digit occupations and wages of either men or women. This is in contrast to the stylized facts of the U.S. literature (see, e.g., Macpherson and Hirsch, 1995) which finds negative effects of female occupational concentration on wages of both genders. Even more striking are the East German estimates in Table 3b: The coefficients on the fraction of females in occupation are both positive and statistically significant. ${ }^{22}$ This flies in the face of both the U.S. evidence and the available work from transition countries.

In Table 5 we assess the sensitivity of our gender segregation estimates to different specifications and sub-samples. Column (1) of Table 5 shows the coefficients on female occupational segregation from regressions including no other controls. While the West German correlations are not statistically significant, the East German estimates are positive and much larger compared to the corresponding parameters of Table 3b. In column (2) we replicate the coefficients based on the preferred specification with all firm and worker controls from Table 3: Both of the East German coefficients are positive and statistically significant. Baker and Fortin (2001) argue that, because of human capital externalities, one should also control for average characteristics of co-workers in an occupation. In column (3) we therefore ask whether higher educational level of workers in the same occupation (but typically a different firm) increases a worker's wage independent of the owneducation effect. ${ }^{23}$ Specifically, we introduce three additional regressors consisting of the fraction

\footnotetext{
${ }^{22}$ The male (female) coefficient is statistically significant at the $1 \%(10 \%)$ level.

${ }^{23}$ It is not clear why women would choose to enter occupations with lower average education level, i.e. low-wage
} 
of an occupation's workforce with a (i) college degree, (ii) Abitur exam, and (iii) apprenticeship degree. The (unreported) regression coefficients corresponding to these additional controls are always positive and statistically significant. However, their introduction leads to no qualitative change in the parameters of interest: The East German segregation coefficients are smaller, but remain positive and statistically significant, while the West German coefficients are still insignificant. Finally, in columns (4) and (5) we re-estimate the preferred specification for the sub-sample of younger and older workers. This is motivated by the differential extent of segregation across age groups (Table 2). We find that the insignificant West German overall coefficients result from a combination of a significant wage penalty to 'female' jobs for workers under 30 years of age and a positive, but statistically weak relationship for older workers. In East Germany, we see that the positive bonus to 'female' jobs comes primarily from older workers.

Next, we check the sensitivity of the OLS estimates to the top coding of IAB wages, which in principle renders OLS inconsistent. So far, we have ignored the issue of right censoring of wages and included the observations with top-coded wages in the OLS estimation. Now, we compare the OLS results to those based on the Censored Least Absolute Deviation (CLAD) estimator proposed by Powell (1984). CLAD is based on the assumption of zero median of the model error distribution. It is not a least-squares but a median (quantile) regression and, unlike parametric censored-regression models (i.e., Tobit), it permits non-normal, heteroscedastic, and asymmetric errors. Column (6) of Table 5 lists the gender segregation coefficients from the median CLAD regressions as well as the bootstrap standard errors. Comparing the new estimates to the Least-Squares parameters from column (2) shows little material difference. Furthermore, Appendix Table A-1, which lists the complete estimated specifications from CLAD regressions, suggests that other coefficients are also little affected. We therefore conclude that ignoring right censoring has a negligible quantitative effect on our parameters, which justifies the mean wage-gap decompositions based on the OLS

occupations. 
estimates. ${ }^{24}$

Up to now, we have estimated worker-level regressions, but our parameters of interest were identified using group-level (occupation-level) variation. We adjusted the variance-covariance matrix (equation 2) to correct standard errors for the different data dimensions used in the estimation of worker- and group-specific coefficients and to allow for correlation of worker unobservables within occupations. There is an alternative way of reflecting the different degrees of freedom involved in estimating the worker-specific and occupation-specific coefficients: One may first estimate a regression with individual-specific regressors only and in a second stage regress the occupational means of residuals or the estimated occupational dummies from the first stage on the share of females in occupation, weighting by the occupation's size. See Dickens and Ross (1984) for an original formulation of the approach and Baker and Fortin (2001) for a discussion of the ramifications of the one-step and two-step estimators for potential biases from occupation-level omitted variables.

We visualize the estimates from column (2) of Table 5 in Figure 4.2 where we plot for each gender and each part of Germany in 1995 the occupation-specific average residual from wage regressions with standard controls (but not occupations' 'femaleness') against the occupation-specific fraction of females. The size of each plotted observation reflects the number of workers in that occupationgender group in the data. The graphs also contain fitted linear weighted-least-squares regression lines. The estimated parameters from these regressions are in full accord with those based on worker-level analysis. Again, both West German coefficients are small (0.03 for men and -0.04 for women) and statistically insignificant, while the East German coefficients are both positive and highly statistically significant (0.08 for both men and women) ${ }^{25}$ We note that weighting by

\footnotetext{
${ }^{24}$ Note that the Oaxaca-Blinder decomposition idea relies on the regression passing through sample means and does not carry over to the quantile regression case.

${ }^{25}$ Introducing the controls for the average education in occupation in the second-step regression leads to a dramatic change in the estimated parameters. In West Germany, both of the segregation coefficients are now negative and statistically significant, while both of the East German parameters are close to zero and insignificant. We interpret these estimates as suggesting that women in East Germany are concentrated in high-skill occupations. (See the next section for further evidence on this interpretation.) On the other hand, using the occupational dummies from the first-stage (instead of log-wage mean residuals by occupation obtained in absence of occupational controls) leads to stronger positive coefficients in the second stage, especially for East Germany. Note, however, that the inclusion of
} 

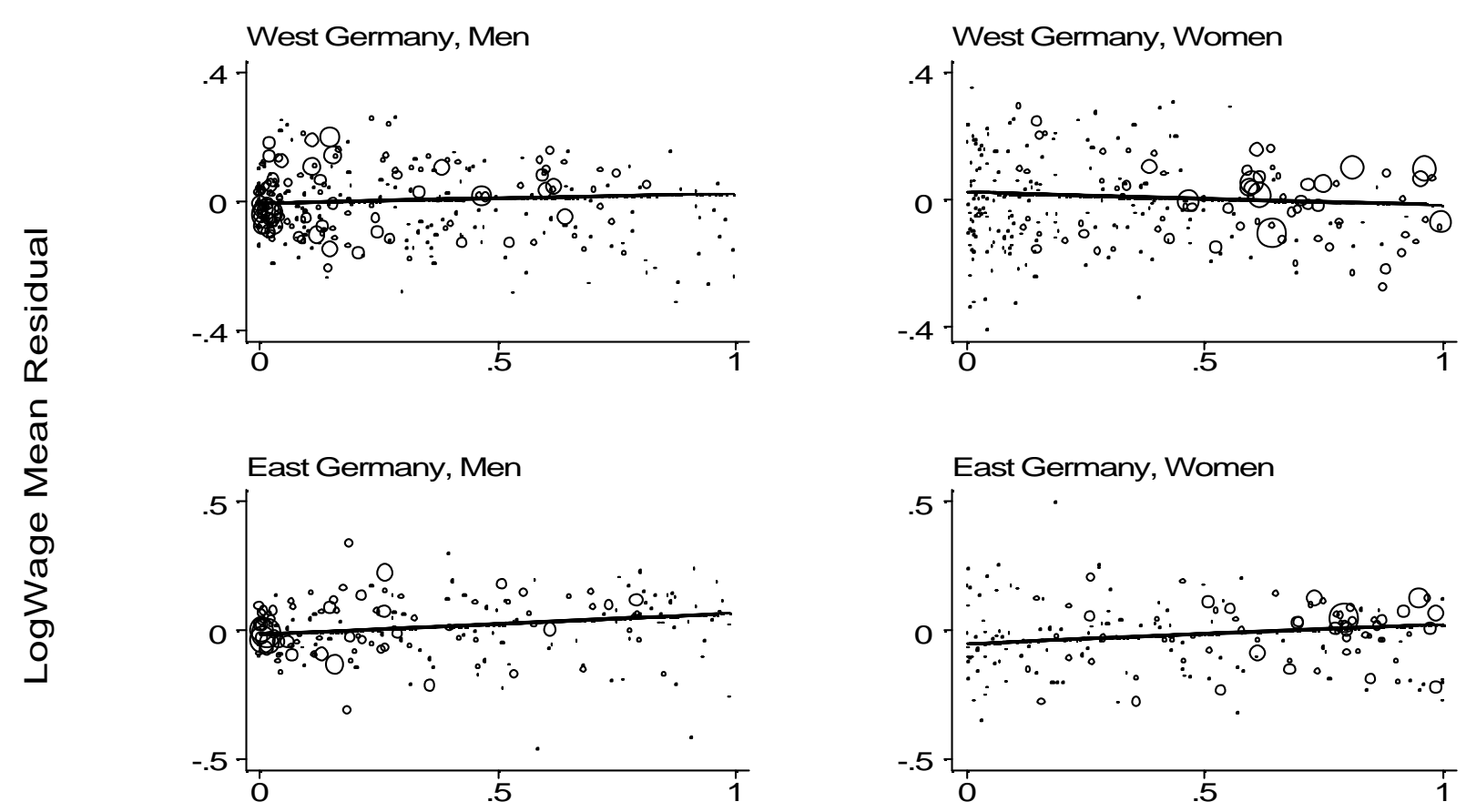

\section{Share of Women in 3-Digit Occupation}

Figure 4.2: Occupation-Level Relationship between Wage Residuals and 'Femaleness' in 1995

occupation's size is important; giving each occupation equal weight would result in a negative effect for West German men.

\subsubsection{Person-Fixed-Effect Specifications}

Our estimates up to now have been based on cross-sectional variation in occupation-specific female concentration. How can we interpret our findings thus far? In particular, why do 'female' occupations pay more in East Germany? In searching for an answer we turn to the specific labor market history and institutions in East Germany. The transition from communism in East Germany led

occupational dummies in the first-stage regression affects the interpretation of the estimated education coefficients. As in the returns-to-education literature, we prefer to filter out the effect of education independent of the (subsequent) choice of occupation. Either approach confirms the finding of a bonus to 'female' occupations in East Germany. 
to a dramatic fall in female employment rates while wage levels rapidly rose to near-western levels. This suggests a marked tendency towards selection of East German women into employment based on labor quality. We know that during early pro-market reforms in East Germany low-wage women were more likely to become jobless while East German men were more likely than women to enter self-employment (become entrepreneurs) and therefore disappear from our data (Hunt, 2002). If entry into self-employment is highly correlated with observed and unobserved quality, the East German men remaining in social-security employment may be of relatively low labor quality. On the other hand, if low-skill women are not employed, the pool of social-security female employees may be of relatively high quality.

Indeed, our Oaxaca-Blinder decomposition in Table 4 suggests that, unlike in West Germany, the observed labor quality of female employees in East Germany is higher than that of their male colleagues. If, as one would expect, there is a positive correlation between observable and unobservable skills of workers (Gibbons and Katz, 1992), East German women may also have better unobservables. A positive correlation between the share of women in an occupation and the occupation-specific unobserved labor quality would then lead to the surprising positive coefficient on occupational 'femaleness' for females. Furthermore, if the share of women in an occupation becomes an index of labor quality, then high-skill men may sort themselves into such occupations (Kremer, 1993), giving rise to a positive effect of occupations' 'femaleness' for males.

One could alternatively explain the positive effect of occupational 'femaleness' on male wages as corresponding to a compensating wage differential for men who would prefer to work with other men, but accept positions in occupations predominantly staffed with women. This explanation is attractive because we know that in Germany wages can differ according to gender within narrowly defined worker groups (Table 1). However, this hypothesis is less useful in explaining why wages of women working in predominantly 'female' occupations are higher compared to those of women working in 'male' occupations. 
If the percentage of females in an occupation serves as a proxy for skill level, then the 'femaleness' coefficients should decline with the introduction into a regression of productivity controls. Comparing columns (1) and (2) of Table 5, we see that this is indeed the case. We can shed more light on the quality sorting hypothesis using the panel dimension of our data. Following Macpherson and Hirsh (1995), we condition on person-specific unobserved labor quality by estimating worker-fixed-effect regressions. ${ }^{26}$ These "within" regressions use a subsample of workers employed in both 1992 and 1995 consisting of 30 and 114 thousand employees in East and West Germany respectively. ${ }^{27}$

It is important to discuss the sources of variation in "within-person" occupation characteristics, such as the share of women. Over time, the 'femaleness' of one's occupation can change both for workers who remain in the same occupation and for those who switch occupations between 1992 and $1995 .{ }^{28}$ To the extent that they are exogenous to gender segregation, occupation moves provide an important source of identification for the segregation effect. The IAB panel we use is rich in that it covers 16 (8) thousand of such occupation moves in West (East) Germany. ${ }^{29}$

Table 6 presents the results based on the 1992-95 panel subsample. First, we check whether the cross-sectional estimates of the penalty to 'female' occupations from column (2) of Table 5 are replicated in the panel subsample. We obtain qualitatively equivalent parameters in column (1) of Table 6 in that the West German occupational 'femaleness' coefficients remain small and are not statistically significant. The East German male coefficient is also in accord with the cross-sectional estimate based on all 1995 workers, but the female parameter is now close to zero. In column (2) of

\footnotetext{
${ }^{26}$ Using fixed-effect regressions to control for unobserved person-specific characteristics is an alternative to estimating sample-selection models of (female) employment participation. In general, participation decisions undoubtedly affect both the extent of segregation and the coefficients of female wage regressions. The estimation (and identification) of such models goes beyond the scope of the recent literature on gender segregation. In our case, we refer the reader to Hunt (2002) for evidence on the role of labor quality for employment participation in East Germany.

${ }^{27}$ The (unreported) cross-sectional parameters from 1992 are very similar to those presented in Table 3 for 1995 (see Prasad, 2000, for evidence on the stability of the German wage structure). Hence, the assumption of constant coefficients across the two years, embedded in the fixed-effect model, is reasonable. At the same time, the 3 year gap is long enough to allow for changes in wages resulting from changes in occupations to take place.

${ }^{28}$ The occupation-level time changes of 'femaleness' separate from those coming from the observed (sample of) occupation moves come from the occupation-gender structure of employment inflow and outflow, which is not captured in the panel sub-sample.

${ }^{29}$ In both parts of Germany, about 70\% of the occupation movers also changes firms between 1992 and 1995.
} 
Table 6 we re-estimate the cross-sectional relationship using the smaller group of occupation movers who provide the strongest source of identification for the "within-person" estimation. Here, we are able to closely replicate both of the East German occupational coefficients as well as the male West German estimate, but the female West German parameter estimate grows and becomes statistically significant (but remains within one standard error of the preferred cross-sectional estimate). Overall, we conclude that the most important feature of our cross-sectional analysis, namely the positive 'bonus' to 'female' occupations in East Germany is preserved in the panel subsamples.

Finally, columns (3) and (4) of Table 6 present the estimates of the effect of an occupation's 'femaleness' on wages based on "within-worker" time-change variation. ${ }^{30}$ These results are not affected by time-constant differences in worker skills and therefore come closer to a causal effect of segregation on wages. Using this different source of variation, we obtain a dramatically different set of coefficients. Conditioning on both observed and unobserved personal characteristics results in negative effects of occupational segregation in West Germany and zero effects in East Germany, completely eliminating its positive cross-sectional occupational segregation coefficients. ${ }^{31}$ This is fully consistent with our explanation of the positive effects as being driven by sorting on unobserved labor quality differences. ${ }^{32}$ On the other hand, this finding is not consistent with the alternative explanation for the male positive 'femaleness' effect based on a compensating wage differential for men who prefer to work with men, but accept working with women.

Using the notation of equation 1 we are now ready to calculate the contribution of gender

\footnotetext{
${ }^{30}$ The clustering of unobservables used to correct standard errors now occurs by occupation pairs across the two years.

${ }^{31}$ In all fixed-effect specifications, we also tried to include a constant term in order to capture the different average growth of wages for East and West Germany, which we would not want to interpret as being caused by differences in the time change of female share on total employment in each part of Germany. These estimates ask whether wage growth was faster, relative to average wage growth in the period, in those occupations where female share grew faster. These results are fully identical to those presented in Table 6, which are based on standard fixed-effect formulas and inflation-adjusted wages.

${ }^{32}$ Further, we note that the quality-sorting hypothesis sheds light on the stronger positive cross-sectional coefficients we obtained for older East German workers in Table 5. Early retirement programs offered at the outset of economic transition in East Germany are likely to have resulted in a particularly strong selection into employment based on labor quality.
} 
segregation to overall wage gaps as $\left(\overline{P_{m}}-\overline{P_{f}}\right)\left[\varphi \widehat{\gamma_{m}}+(1-\varphi) \widehat{\gamma_{f}}\right]$, where $\varphi$ is the share of males in full-time social-security employment, $\widehat{\gamma}_{s}$ are the estimated gender-specific segregation coefficients, and where $\overline{P_{s}}$ contains the averages of the female-share regressor for each gender.

We perform this calculation twice, in both cases using the cross-sectional mean differences in $P$ from 1995. First, we use the cross-sectional parameter estimates from column (2) of Table 5. The calculation suggests that in West Germany gender segregation does not explain any part of the overall wage gap, while in East Germany it makes female wages 5.5 percentage points higher than male wages. Second, we use the 'causal-effect' panel-data coefficients based on occupational movers (column (4) of Table 6). Here, we find that in West Germany gender segregation explains 2 percentage points of the overall wage gap, but it gives rise to no gender-related wage differences in the east part of Germany. Overall, we believe that our panel-data results point to (i) high unobserved quality of East German female employees leading to a positive sorting on skills across occupations, and (ii) a very small causal contribution of gender segregation toward explaining the overall wage gaps in both parts of Germany.

\section{Conclusions}

This paper sheds light on the size of the gender wage gap, the extent of occupational gender segregation, and on the effects segregation has on the gender pay differences in East and West Germany in 1995. The analysis is based on full-time employees only and does not cover civil servants and the self-employed.

Our analysis uncovers intriguing East-West differences. We find a somewhat higher degree of gender segregation across occupations in East Germany, where women form a larger share of total social-security employment. Yet, the female structure of employment is very similar in East and West Germany, despite the different history.

Strikingly, there are no median wage differences between workers of different genders in East 
Germany. Our East German data also imply a very small unconditional mean daily wage gap in the order of one fifth of the West German gap. In contrast, the mean (median) wage gap in West Germany is substantial at $30(22)$ percent. Despite the difference in the overall wage gaps, we uncover significant wage gaps within jobs (occupation-firm cells) in both parts of Germany.

Our regression analysis reconciles these pieces of descriptive evidence: We find little support for the existence of a wage penalty to 'female' jobs in West Germany. Occupational segregation therefore does not explain the greater wage gap in West Germany. The significant within-job wage gaps in East Germany do not appear at the aggregate level because more 'female' occupations actually offer higher wages, in striking contrast to findings from the U.S. as well as from transition countries.

We suggest a possible interpretation for this finding based on the unique nature of transition from central planning in East Germany. German unification brought about the imposition of nearwestern wage levels against a background of mass layoffs. We know that this resulted in a strong selection of women into employment based on labor quality (Hunt, 2002). Indeed, productive characteristics of our East German female employees are higher than those of their male colleagues. If the share of women in an occupation becomes a measure of skill quality, high productivity men may sort themselves into predominantly 'female' occupations.

We explore the implications of this hypothesis in terms of unobservable skills using the longitudinal portion of the data. Following the existing literature, we assume that workers switch occupations for reasons unrelated to gender segregation, and use the resulting "within-worker" time variation in 'femaleness' of occupations to estimate worker-fixed-effect regressions. Conditioning on unobservable labor quality differences, as well as all other time-constant worker characteristics, we find no evidence of a causal effect of occupational segregation on East German wages. This is consistent with the quality sorting hypothesis, but not with other explanations for the East German 'bonus' to 'female' jobs. 
Our analysis has implications for both gender public policy and the existing literature on occupational gender segregation. First, we suggest that discriminatory crowding of women into low-wage occupations is not important in Germany, including its east lands where anti-discriminatory laws were introduced only recently. However, we find the potential scope for violations of the equal pay clauses to be significant in both parts of Germany. In West Germany, workplace gender segregation combines with an uneven distribution of productive characteristics to account for up to 10 percentage points of the overall 30-percent difference between the mean wages of men and women, which leaves over two thirds of the gap unexplained. In East Germany, the low overall wage gap is in part due to the distribution of both observable and unobservable productive characteristics favorable to women. ${ }^{33}$

Second, our evidence implies that the negative cross-sectional relationship between 'femaleness' of occupations and wages of both men and women, omnipresent in U.S. and other research, may not stand in other developed economies. Female employment rates in Germany are low compared to other developed countries. Our findings suggest that if mainly highly productive women are employed (due to, e.g., high wage floors), this may eliminate the typical negative correlation between the share of females in occupation and wage level in that occupation. Similarly, comparing our results to findings from transition economies is also suggestive. Wage levels in most transition economies rose only slowly and wage floors are still low compared to East Germany. The existing studies on occupational gender segregation in post-communist countries find a significant wage penalty to predominantly 'female' occupation classes. We believe that these casual comparisons motivate future cross-country research linking the size of the wage penalty to 'female' occupations with wage floors and skill structure of female employment. Such research would be complementary to the within-country longitudinal studies, which control for unobservable worker skills by relying

\footnotetext{
${ }^{33}$ One possible explanation for the whole of our findings is that in Germany (both East and West) discrimination against women did not take the form of segregation because it was possible to differentiate wages by gender directly within narrowly defined worker groups.
} 
on the exogeneity of worker occupation moves.

\section{Bibliography}

Baker, M., and N.M. Fortin (1999) "Women's Wages in Women's Work: A U.S./Canada Comparison of the Roles of Unions and "Public Goods" Sector Jobs," American Economic Review, 89 (2): 198-203.

Baker, M., and N.M. Fortin (2001) "Occupational Gender Composition and Wages in Canada, 1987-1988," Canadian Journal of Economics, 34 (2): 345-376.

Bayard, K., Hellerstein, J., Neumark D. and K. Troske (in press) "New Evidence on gender Segregation and gender Differences in Wages from Matched Employee-Employer Data," forthcoming in Journal of Labor Economics.

Beaudry, P., and D.A. Green (2003) "Wages and Employment in the United States and Germany: What Explains the Difference?" American Economic Review, 93 (3): 573-602.

Bender, Stefan, Haas, Anette, and Christoph Klose (2000) "IAB Employment Subsample 1975-1995 Opportunities for Analysis Provided by the Anonymised Subsample," IZA Discussion Paper No. 117.

Bertola, G., Blau F.D., and L. Kahn (2002) "Labor Market Institutions and Demographic Employment Patterns," CEPR Discussion Paper No. 3448.

Blau F.D. and L.M. Kahn (2003) "Understanding international differences in the gender pay gap," Journal of Labor Economics, 21 (1), 106-144.

Bonin, H. and R. Euwals (2002) "Participation Behavior of East German Women After German Unification," CEPR Discussion Paper No. 3201.

Brainerd, E. (1998) "Winners and Losers in Transition," American Economic Review, 88(5), 1094-1116.

Brainerd, E. (2000) "Women in Transition: Changes in Gender Wage Differentials in Eastern Europe and the Former Soviet Union," Industrial and Labor Relations Review, 54(1), 138-162.

Burda, M., and J. Hunt (2001) "From Reunification to Economic Integration: Productivity and Labor Markets in Germany," Brookings Papers on Economic Activity, 2:1-71.

Dickens, W.T., and B.A. Ross (1984) "Consistent Estimation Using Data from More than One Sample," Technical Working Paper no. 33, Cambridge, MA: National Bureau of Economic Research.

Duncan, O.T., and B. Duncan (1955) "A Methodological Analysis of Segregation Indexes", American Sociological Review, 20: 210-217.

Filer, R.K. (1986) "The Role of Personality and Tastes in Determining Occupational Structure," Industrial and Labor Relations Review, 39 (3): 412-424.

Freeman, R.B., and R. Schettkat (2000) "The Role of Wage and Skill Differences in US-German Employment Differences," NBER Working Paper No. 7474. 
Gibbons, Robert, and Lawrence F. Katz (1992) "Does Unmeasured Ability Explain Inter-industry Wage Differentials?" Review of Economic Studies, 59(3): 515-35.

Groshen, E.L. (1991) "The Structure of the Female/Male Wage Differential: Is it Who You Are, What You Do, or Where You Work?," Journal of Human Resources, 26 (3), 457-72.

Hunt, J. (2002) "The Transition in East Germany: When is a Ten Per Cent Fall in the Gender Pay Gap Bad News," Journal of Labor Economics, 20 (1), 148-169.

Jolliffe, D. (2001) "The Gender Wage Gap in Bulgaria: A Semiparametric Estimation of Discrimination," William Davidson Institute Working Paper No. 401.

Jurajda, S̆. (2003) "Gender Wage Gap and Segregation in Enterprises and the Public Sector in Late Transition Countries," Journal of Comparative Economics, 31 (2), pp. 199-222.

Killingsworth, M. (1990) The Economics of Comparable Worth, Kalamazoo, Michigan: W. E. Upjohn Institute for Employment Research.

Kremer, M. (1993) "The O-ring theory of Economic Development," Quarterly Journal of Economics, 108 (3), 551 575.

Macpherson, D., and B.T. Hirsh (1995) "Wages and Gender Composition: Why Do Women's Jobs Pay Less," Journal of Labor Economics, 13, 426-471.

Newell, A., and B. Reilly (2000) "The Gender Wage Gap in the Transition from Communism: Some Empirical Evidence," William Davidson Institute Working Paper No. 305.

Oaxaca, R. (1973) "Male-Female Wage Differentials in Urban Labor Markets," International Economic Review, 14(3), 693-709.

Oaxaca, R. and M.R. Ransom (1994) "On Discrimination and the Decomposition of Wage Differentials," Journal of Econometrics, 61, 5-21.

Ogloblin, C.G. (1999) "The Gender Earnings Differential in the Russian Transition Economy," Industrial and Labor Relations Review, 52(4), 602-27.

Powel, J.L. (1984) "Least Absolute Deviation Estimation for the Censored Regression Model," Journal of Econometrics, 25(3), 303-25.

Pannenberg, M. (2002) "Long-Term Effects of Unpaid Overtime: Evidence for West Germany" IZA Discussion Paper No. 614 .

Riphahn, T., Snower, D. J., and K. F. Zimmermann, eds. (2001) Employment Policy in Transition: The Lessons of German Integration for the Labour Market, Springer-Verlag, Heidelberg.

Wolf, E. (2002) "Lower Wage Rates for Fewer Hours? A Simultaneous Wage-Hours Model for Germany ," Labour Economics, 9, 643-663. 
Table 1: Descriptive Statistics of the IAB and GSOEP 1995 Worker Samples ${ }^{\text {a }}$

\begin{tabular}{|c|c|c|c|c|}
\hline & \multicolumn{2}{|c|}{$\mathrm{IAB}^{\mathrm{b}}$} & \multicolumn{2}{|c|}{ GSOEP $^{c}$} \\
\hline & West & East & West & East \\
\hline \multicolumn{5}{|c|}{ Demographic Composision } \\
\hline Mean age & 39.1 & 39.6 & 39.4 & 40.4 \\
\hline Female $(\%)$ & 33.1 & 38.9 & 33.2 & 40.1 \\
\hline \multicolumn{5}{|l|}{ Education (\%) } \\
\hline No apprenticeship, no abitur & 13.4 & 4.4 & 13.5 & 4.0 \\
\hline Apprenticeship, no abitur & 72.5 & 78.9 & 69.7 & 78.3 \\
\hline Abitur & 4.7 & 3.4 & 5.4 & 6.0 \\
\hline College or university & 9.4 & 13.3 & 11.5 & 11.7 \\
\hline Firm size $<20$ workers $(\%)$ & 23.2 & 24.9 & 19.3 & 26.2 \\
\hline No. of workers & 141,222 & 40,094 & 2,034 & 1,425 \\
\hline No. of firms & 84,307 & 25,349 & -- & -- \\
\hline \multicolumn{5}{|c|}{ Wages and Gender Wage Gaps } \\
\hline Median daily wage $^{\mathrm{d}}$ & 153 & 109 & 210 & 150 \\
\hline Median gender wage gap ${ }^{e}$ & 21.8 & -0.9 & 22.2 & 3.2 \\
\hline Median gap within job cells ${ }^{\mathrm{f}}$ & 14.5 & 6.7 & -- & -- \\
\hline No. of job cells & 5,044 & 1,349 & -- & $\overline{--}$ \\
\hline Avg. no. of workers per firm in data & 10.5 & 4.8 & -- & -- \\
\hline
\end{tabular}

${ }^{\text {a }}$ Observations for full-time workers with gross daily wage above 60DM; no civil servants, self-employed, home workers, or trainees, and no non-Germans.

${ }^{\mathrm{b}}$ Sample based on a cross-section of end-of-year social-security notifications.

${ }^{\mathrm{c}}$ Sub-sample mimicking the IAB data (a); person-specific cross-sectional weights are used.

${ }^{\mathrm{d}}$ GSOEP daily wages approximated by dividing monthly salaries by hours worked. ???

${ }^{\mathrm{e}}$ Female Wage Disadvantage as $\%$ of Male Wage $\left(1-\mathrm{w}_{\mathrm{f}} / \mathrm{w}_{\mathrm{m}}\right)$

${ }^{\mathrm{f}} \mathrm{A}$ job cell consists of workers in the same firm with the same occupation. 
Table 2: Occupational Segregation by Demographic Characteristics

\begin{tabular}{|c|c|c|c|c|c|c|}
\hline \multirow[b]{2}{*}{ Education } & \multicolumn{4}{|c|}{ "Duncan Segregation Index } & \multicolumn{2}{|c|}{ "Group's Share of Employment (\%) } \\
\hline & Age group & West Germany & East Germany & Difference & West Germany & East Germany \\
\hline \multirow{2}{*}{ No apprenticeship, no abitur } & $30-44$ & 60 & 69 & 9 & 5 & 2 \\
\hline & $>44$ & 62 & 67 & 4 & 6 & 2 \\
\hline \multirow{3}{*}{ Apprenticeship, no abitur } & $<30$ & 68 & 74 & 7 & 19 & 16 \\
\hline & $30-44$ & 65 & 71 & 6 & 30 & 38 \\
\hline & $>44$ & 67 & 69 & 1 & 24 & 25 \\
\hline \multirow{2}{*}{ College or university } & $30-44$ & 41 & 40 & -1 & 5 & 7 \\
\hline & $>44$ & 61 & 43 & -19 & 3 & 6 \\
\hline
\end{tabular}


Table 3a: Estimated Log-Daily-Wage OLS Regressions for 1995 West Germany

\begin{tabular}{|c|c|c|c|c|c|c|c|c|}
\hline & \multicolumn{4}{|c|}{ Men } & \multicolumn{4}{|c|}{ Women } \\
\hline & $\begin{array}{c}\text { coeff. } \\
\text { (1) }\end{array}$ & std.error & $\begin{array}{c}\text { coeff. } \\
(2)\end{array}$ & std.error & $\begin{array}{c}\text { coeff. } \\
\text { (3) }\end{array}$ & std.error & $\begin{array}{c}\text { coeff. } \\
(4)\end{array}$ & std.error \\
\hline$\overline{\text { Fraction of females in occupation }}$ & - & & 0.037 & $(0.034)$ & - & & -0.054 & $(0.07)$ \\
\hline$\overline{\text { Married }}$ & 0.073 & $(0.003)$ & 0.073 & $(0.003)$ & -0.052 & $(0.006)$ & -0.052 & $(0.006)$ \\
\hline Number of Children & -0.015 & $(0.004)$ & -0.014 & $(0.004)$ & -0.011 & $(0.006)$ & -0.012 & $(0.006)$ \\
\hline Age & 0.036 & $(0.003)$ & 0.036 & $(0.003)$ & 0.038 & $(0.002)$ & 0.038 & $(0.002)$ \\
\hline Age*Age/100 & -0.035 & $(0.003)$ & -0.035 & $(0.003)$ & -0.041 & $(0.002)$ & -0.041 & $(0.002)$ \\
\hline Apprenticeship, No GCE & 0.178 & $(0.015)$ & 0.177 & $(0.016)$ & 0.183 & $(0.02)$ & 0.187 & $(0.021)$ \\
\hline Secondary Educ. with GCE & 0.306 & $(0.024)$ & 0.303 & $(0.027)$ & 0.285 & $(0.024)$ & 0.287 & $(0.024)$ \\
\hline University and more & 0.452 & $(0.015)$ & 0.451 & $(0.016)$ & 0.473 & $(0.038)$ & 0.465 & $(0.034)$ \\
\hline Chemical \& Metal & 0.156 & $(0.033)$ & 0.157 & $(0.033)$ & 0.147 & $(0.031)$ & 0.149 & $(0.03)$ \\
\hline Textile \& Household Goods & 0.094 & $(0.036)$ & 0.090 & $(0.036)$ & -0.050 & $(0.044)$ & -0.045 & $(0.042)$ \\
\hline Mining \& Quarrying & 0.178 & $(0.034)$ & 0.177 & $(0.034)$ & 0.139 & $(0.03)$ & 0.139 & $(0.029)$ \\
\hline Manufacturing & 0.179 & $(0.033)$ & 0.179 & $(0.033)$ & 0.136 & $(0.029)$ & 0.138 & $(0.027)$ \\
\hline Utilities & 0.252 & $(0.035)$ & 0.252 & $(0.035)$ & 0.247 & $(0.033)$ & 0.256 & $(0.031)$ \\
\hline Construction & 0.174 & $(0.033)$ & 0.177 & $(0.033)$ & 0.133 & $(0.031)$ & 0.138 & $(0.029)$ \\
\hline Trade & 0.146 & $(0.039)$ & 0.141 & $(0.04)$ & 0.070 & $(0.04)$ & 0.076 & $(0.038)$ \\
\hline Transport & 0.107 & $(0.039)$ & 0.106 & $(0.038)$ & 0.152 & $(0.031)$ & 0.155 & $(0.031)$ \\
\hline Banks \& Insurance & 0.306 & $(0.033)$ & 0.296 & $(0.035)$ & 0.308 & $(0.028)$ & 0.310 & $(0.027)$ \\
\hline Business Services & 0.240 & $(0.033)$ & 0.237 & $(0.033)$ & 0.239 & $(0.03)$ & 0.242 & $(0.028)$ \\
\hline Public Administration & 0.075 & $(0.033)$ & 0.069 & $(0.032)$ & 0.164 & $(0.026)$ & 0.175 & $(0.029)$ \\
\hline Education & 0.098 & $(0.032)$ & 0.093 & $(0.033)$ & 0.189 & $(0.04)$ & 0.204 & $(0.047)$ \\
\hline Health & 0.106 & $(0.035)$ & 0.098 & $(0.037)$ & 0.103 & $(0.044)$ & 0.121 & $(0.049)$ \\
\hline Other Services & 0.069 & $(0.046)$ & 0.061 & $(0.048)$ & 0.083 & $(0.035)$ & 0.093 & $(0.034)$ \\
\hline Firm employment: 50-99 & 0.077 & $(0.006)$ & 0.077 & $(0.006)$ & 0.106 & $(0.012)$ & 0.105 & $(0.011)$ \\
\hline $100-499$ & 0.107 & $(0.008)$ & 0.106 & $(0.009)$ & 0.161 & $(0.014)$ & 0.159 & $(0.013)$ \\
\hline over 500 & 0.155 & $(0.004)$ & 0.155 & $(0.01)$ & 0.247 & $(0.005)$ & 0.245 & $(0.013)$ \\
\hline Constant & 3.835 & $(0.015)$ & 3.895 & $(0.091)$ & 3.659 & $(0.026)$ & 3.776 & $(0.101)$ \\
\hline R-squared & & 38 & & 40 & & 32 & & 34 \\
\hline
\end{tabular}

Note: There are 274 occupations. Agriculture, elementary education, and firm size below 50 workers are in the base case.

Standard errors allow for occupational clustering of errors. 
Table 3b: Estimated Log-Daily-Wage OLS Regressions for 1995 East Germany

\begin{tabular}{|c|c|c|c|c|c|c|c|c|}
\hline & \multicolumn{4}{|c|}{ Men } & \multicolumn{4}{|c|}{$\overline{\text { Women }}$} \\
\hline & $\begin{array}{c}\text { coeff. } \\
\text { (1) }\end{array}$ & std.error & $\begin{array}{c}\text { coeff. } \\
\text { (2) }\end{array}$ & std.error & $\begin{array}{c}\text { coeff. } \\
\text { (3) }\end{array}$ & std.error & $\begin{array}{c}\text { coeff. } \\
\text { (4) }\end{array}$ & std.error \\
\hline Fraction of females in occupation & - & & 0.124 & $(0.034)$ & - & & 0.095 & $(0.056)$ \\
\hline Married & 0.053 & $(0.005)$ & 0.054 & $(0.005)$ & 0.013 & $(0.005)$ & 0.012 & $(0.005)$ \\
\hline Number of Children & -0.007 & $(0.005)$ & -0.006 & $(0.005)$ & -0.005 & $(0.006)$ & -0.005 & $(0.006)$ \\
\hline Age & 0.019 & $(0.002)$ & 0.019 & $(0.002)$ & 0.028 & $(0.002)$ & 0.028 & $(0.002)$ \\
\hline Age*Age/100 & -0.020 & $(0.002)$ & -0.021 & $(0.002)$ & -0.029 & $(0.003)$ & -0.030 & $(0.003)$ \\
\hline Apprenticeship, No GCE & 0.083 & $\overline{(0.018)}$ & 0.083 & $\begin{array}{c}(0.018) \\
\end{array}$ & 0.166 & $\overline{(0.021)}$ & 0.154 & $(0.022)$ \\
\hline Secondary Educ. with GCE & 0.295 & $(0.031)$ & 0.282 & $(0.033)$ & 0.293 & $(0.039)$ & 0.283 & $(0.042)$ \\
\hline University and more & 0.456 & $(0.03)$ & 0.438 & $(0.036)$ & 0.458 & $(0.041)$ & 0.456 & $(0.043)$ \\
\hline Chemical \& Metal & 0.160 & $(0.016)$ & 0.179 & $(0.018)$ & 0.115 & $(0.04)$ & 0.108 & $(0.037)$ \\
\hline Textile \& Household Goods & 0.097 & $(0.026)$ & 0.096 & $(0.028)$ & 0.024 & $(0.03)$ & 0.016 & $(0.032)$ \\
\hline Mining \& Quarrying & 0.160 & $(0.019)$ & 0.170 & $(0.02)$ & 0.165 & $(0.025)$ & 0.161 & $(0.026)$ \\
\hline Manufacturing & 0.206 & $(0.019)$ & 0.219 & $(0.02)$ & 0.172 & $(0.022)$ & 0.162 & $(0.022)$ \\
\hline Utilities & 0.346 & $(0.02)$ & 0.360 & $(0.022)$ & 0.398 & $(0.021)$ & 0.382 & $(0.024)$ \\
\hline Construction & 0.214 & $(0.019)$ & 0.235 & $(0.021)$ & 0.231 & $(0.016)$ & 0.216 & $(0.021)$ \\
\hline Trade & 0.172 & $(0.034)$ & 0.170 & $(0.034)$ & 0.198 & $(0.035)$ & 0.181 & $(0.038)$ \\
\hline Transport & 0.221 & $(0.033)$ & 0.232 & $(0.029)$ & 0.337 & $(0.023)$ & 0.320 & $(0.023)$ \\
\hline Banks \& Insurance & 0.419 & $(0.031)$ & 0.375 & $(0.038)$ & 0.509 & $(0.021)$ & 0.479 & $(0.023)$ \\
\hline Business Services & 0.326 & $(0.022)$ & 0.332 & $(0.022)$ & 0.363 & $(0.024)$ & 0.347 & $(0.027)$ \\
\hline Public Administration & 0.213 & $(0.037)$ & 0.196 & $(0.026)$ & 0.324 & $(0.026)$ & 0.296 & $(0.029)$ \\
\hline Education & 0.235 & $(0.038)$ & 0.220 & $(0.032)$ & 0.371 & $(0.045)$ & 0.347 & $(0.044)$ \\
\hline Health & 0.259 & $(0.024)$ & 0.254 & $(0.025)$ & 0.303 & $(0.065)$ & 0.264 & $(0.06)$ \\
\hline Other Services & 0.163 & $(0.041)$ & 0.142 & $(0.043)$ & 0.217 & $(0.036)$ & 0.192 & $(0.036)$ \\
\hline Firm employment: 50-99 & 0.057 & $(0.009)$ & 0.057 & $(0.009)$ & 0.068 & $(0.018)$ & 0.072 & $(0.017)$ \\
\hline $100-499$ & 0.093 & $(0.013)$ & 0.091 & $(0.013)$ & 0.096 & $(0.024)$ & 0.101 & $(0.023)$ \\
\hline over 500 & 0.148 & $(0.009)$ & 0.145 & $(0.017)$ & 0.176 & $(0.025)$ & 0.180 & $(0.025)$ \\
\hline Constant & 3.902 & $(0.026)$ & 3.842 & $(0.054)$ & 3.519 & $(0.034)$ & 3.373 & $(0.084)$ \\
\hline R-squared & & 34 & & 39 & & 38 & & 40 \\
\hline
\end{tabular}

Note: There are 274 occupations. Agriculture, elementary education, and firm size below 50 workers are in the base case. Standard errors allow for occupational clustering of errors. 
Table 4: Wage Gap Contribution of Worker and Firm Characteristics in 1995

\begin{tabular}{|c|c|c|c|c|c|c|}
\hline & $\begin{array}{c}\text { Average } \\
\text { Coefficient } \\
\text { (1) }\end{array}$ & $\begin{array}{l}\text { Difference } \\
\text { in Mean X } \\
(2)\end{array}$ & $\begin{array}{c}\text { Absolute } \\
\text { Contribution } \\
(1) *(2)\end{array}$ & $\begin{array}{c}\text { Average } \\
\text { Coefficient } \\
(3)\end{array}$ & $\begin{array}{c}\text { Difference } \\
\text { in Mean X } \\
(4)\end{array}$ & $\begin{array}{c}\text { Absolute } \\
\text { Contribution } \\
(3)^{*}(4)\end{array}$ \\
\hline & \multicolumn{3}{|c|}{ West Germany } & \multicolumn{3}{|c|}{ East Germany } \\
\hline Married & 0.032 & 0.177 & 0.006 & 0.038 & -0.045 & -0.002 \\
\hline Number of Children & -0.014 & 0.052 & -0.001 & -0.008 & 0.069 & -0.001 \\
\hline Age & 0.037 & 3.205 & 0.117 & 0.022 & -0.158 & -0.004 \\
\hline Age*Age/100 & -0.037 & 2.405 & -0.089 & -0.024 & -0.055 & 0.001 \\
\hline Apprenticeship, No GCE & 0.179 & -0.002 & 0.000 & 0.114 & 0.003 & 0.000 \\
\hline Secondary Educ. with GCE & 0.299 & -0.025 & -0.007 & 0.293 & -0.017 & -0.005 \\
\hline University and more & 0.459 & 0.050 & 0.023 & 0.451 & -0.010 & -0.005 \\
\hline Chemical \& Metal & 0.153 & 0.043 & 0.007 & 0.141 & 0.060 & 0.008 \\
\hline Textile \& Household Goods & 0.046 & -0.016 & -0.001 & 0.067 & -0.009 & -0.001 \\
\hline Mining \& Quarrying & 0.165 & 0.052 & 0.009 & 0.161 & 0.033 & 0.005 \\
\hline Manufacturing & 0.165 & 0.108 & 0.018 & 0.191 & 0.054 & 0.010 \\
\hline Utilities & 0.251 & 0.020 & 0.005 & 0.362 & 0.013 & 0.005 \\
\hline Construction & 0.160 & 0.083 & 0.013 & 0.220 & 0.205 & 0.045 \\
\hline Trade & 0.121 & -0.048 & -0.006 & 0.181 & 0.005 & 0.001 \\
\hline Transport & 0.122 & 0.029 & 0.004 & 0.265 & 0.033 & 0.009 \\
\hline Banks \& Insurance & 0.307 & -0.025 & -0.008 & 0.451 & -0.030 & -0.014 \\
\hline Business Services & 0.240 & -0.002 & 0.000 & 0.338 & -0.005 & -0.002 \\
\hline Public Administration & 0.104 & -0.042 & -0.004 & 0.255 & -0.180 & -0.046 \\
\hline Education & 0.128 & -0.026 & -0.003 & 0.288 & -0.045 & -0.013 \\
\hline Health & 0.105 & -0.100 & -0.011 & 0.273 & -0.092 & -0.025 \\
\hline Other Services & 0.073 & -0.080 & -0.006 & 0.182 & -0.055 & -0.010 \\
\hline Firm employment: 50-99 & 0.087 & 0.005 & 0.000 & 0.061 & 0.028 & 0.002 \\
\hline $100-499$ & 0.125 & 0.003 & 0.000 & 0.093 & -0.034 & -0.003 \\
\hline over 500 & 0.185 & 0.055 & 0.010 & 0.158 & -0.104 & -0.017 \\
\hline Total contribution & & & 0.075 & & & -0.058 \\
\hline
\end{tabular}

Note: Column (1) is the female-employment-share weighted average of columns (1) and (3) of Tables 3a and 3b. 
Table 5: Occupational Gender Composition Coefficients from Cross-Sectional Specifications

\begin{tabular}{|c|c|c|c|c|c|c|c|c|c|c|c|c|}
\hline & $\begin{array}{l}\text { coeff. } \\
(1)\end{array}$ & std.error & $\begin{array}{c}\text { coeff. } \\
(2)\end{array}$ & std.error & $\begin{array}{c}\text { coeff. } \\
(3)\end{array}$ & std.error & $\begin{array}{c}\text { coeff. } \\
(4)\end{array}$ & std.error & $\begin{array}{c}\text { coeff. } \\
(5)\end{array}$ & std.error & $\begin{array}{c}\text { coeff. } \\
(6)\end{array}$ & std.error \\
\hline & \multicolumn{12}{|c|}{ West Germany } \\
\hline$\overline{\text { Men }}$ & 0.057 & $(0.065)$ & 0.037 & $(0.034)$ & -0.027 & $(0.026)$ & -0.055 & $(0.03)$ & 0.079 & $(0.052)$ & 0.043 & $(0.005)$ \\
\hline \multirow[t]{2}{*}{ Women } & -0.138 & $(0.105)$ & -0.054 & $(0.07)$ & -0.002 & $(0.052)$ & -0.090 & $(0.049)$ & 0.008 & $(0.097)$ & -0.049 & $(0.009)$ \\
\hline & \multicolumn{12}{|c|}{ East Germany } \\
\hline Men & 0.295 & $(0.063)$ & 0.124 & $(0.034)$ & 0.057 & $(0.029)$ & 0.05 & $(0.03)$ & 0.167 & $(0.044)$ & 0.097 & $(0.012)$ \\
\hline Women & 0.138 & $(0.085)$ & 0.095 & $(0.056)$ & 0.065 & $(0.039)$ & 0.041 & $(0.054)$ & 0.132 & $(0.071)$ & 0.109 & $(0.011)$ \\
\hline Estimator & \multirow{2}{*}{\multicolumn{2}{|c|}{$\begin{array}{l}\text { Least Squares } \\
\text { all workers }\end{array}$}} & \multirow{2}{*}{\multicolumn{2}{|c|}{$\begin{array}{l}\text { Least Squares } \\
\text { all workers }\end{array}$}} & \multirow{2}{*}{\multicolumn{2}{|c|}{$\begin{array}{l}\text { Least Squares } \\
\text { all workers }\end{array}$}} & \multirow{2}{*}{\multicolumn{2}{|c|}{$\begin{array}{c}\text { Least Squares } \\
\text { age }<30\end{array}$}} & \multirow{2}{*}{\multicolumn{2}{|c|}{$\begin{array}{c}\text { Least Squares } \\
\text { age }>44\end{array}$}} & \multicolumn{2}{|c|}{ CLAD } \\
\hline Sample & & & & & & & & & & & all $\mathrm{v}$ & rkers \\
\hline Standard controls & \multicolumn{2}{|c|}{ No } & \multicolumn{2}{|c|}{ Yes } & \multicolumn{2}{|c|}{ Yes+Avg Educ. in Occ. } & \multicolumn{2}{|c|}{ Yes } & \multicolumn{2}{|c|}{ Yes } & \multicolumn{2}{|c|}{ Yes } \\
\hline
\end{tabular}

Note: For a list of standard controls see Table 3. Least-Squares standard errors allow for occupational clustering of unobservables.

Table 6: Occupational Gender Composition Coefficients from the 1992-1995 Panel Sub-Sample

\begin{tabular}{|c|c|c|c|c|c|c|c|c|}
\hline & $\begin{array}{c}\text { coeff. } \\
(1)\end{array}$ & std.error & $\begin{array}{c}\text { coeff. } \\
(2)\end{array}$ & std.error & $\begin{array}{c}\text { coeff. } \\
(3)\end{array}$ & std.error & $\begin{array}{c}\text { coeff. } \\
(4)\end{array}$ & std.error \\
\hline & & & & & \multicolumn{4}{|c|}{ West Germany } \\
\hline$\overline{\text { Men }}$ & 0.057 & $(0.036)$ & 0.070 & $(0.045)$ & -0.034 & $(0.014)$ & -0.035 & $(0.014)$ \\
\hline \multirow[t]{2}{*}{ Women } & -0.050 & $(0.073)$ & -0.128 & $(0.073)$ & -0.091 & $(0.023)$ & -0.078 & $(0.022)$ \\
\hline & & & & & \multicolumn{4}{|c|}{ East Germany } \\
\hline$\overline{\text { Men }}$ & 0.152 & $(0.032)$ & 0.164 & $(0.037)$ & -0.014 & $(0.031)$ & 0.008 & $(0.025)$ \\
\hline Women & 0.020 & $(0.047)$ & 0.111 & $(0.054)$ & -0.024 & $(0.053)$ & 0.029 & $(0.038)$ \\
\hline$\overline{\text { Estimator }}$ & \multirow{3}{*}{\multicolumn{2}{|c|}{$\begin{array}{c}\text { Least Squares } \\
\text { all workers } \\
\text { Yes }\end{array}$}} & \multirow{3}{*}{\multicolumn{2}{|c|}{$\begin{array}{c}\text { Least Squares } \\
\text { ccupation movers } \\
\text { Yes }\end{array}$}} & \multirow{3}{*}{\multicolumn{2}{|c|}{$\begin{array}{c}\text { Person Fixed Effect } \\
\text { all workers } \\
\text { Yes }\end{array}$}} & \multirow{3}{*}{\multicolumn{2}{|c|}{$\begin{array}{c}\text { Person Fixed Effect } \\
\text { occupation movers } \\
\text { Yes }\end{array}$}} \\
\hline Sample & & & & & & & & \\
\hline Standard controls & & & & & & & & \\
\hline
\end{tabular}

Note: For a list of standard controls see Table 3. The panel subsample is based on workers employed in both 1992 and

1995. Standard errors allow for occupational clustering of unboservables; in columns (3) and (4) the clusters correspond to

pairs of occupations across the two years. 
Table A-1: Coefficient Estimates from CLAD Regressions

\begin{tabular}{|c|c|c|c|c|}
\hline & \multicolumn{2}{|c|}{ West Germany } & \multicolumn{2}{|c|}{ East Germany } \\
\hline & Men & Women & Men & Women \\
\hline$\overline{\text { Female fraction in occ. }}$ & 0.043 & -0.049 & 0.097 & 0.109 \\
\hline Married & 0.077 & -0.011 & 0.054 & 0.020 \\
\hline Number of Children & -0.021 & -0.011 & -0.011 & -0.005 \\
\hline Age & 0.036 & 0.042 & 0.019 & 0.034 \\
\hline Age*Age/100 & -0.034 & -0.044 & -0.020 & -0.037 \\
\hline Apprent., no GCE & 0.186 & 0.198 & 0.089 & 0.186 \\
\hline Secondary Educ. GCE & 0.342 & 0.266 & 0.264 & 0.273 \\
\hline University and more & 0.566 & 0.545 & 0.507 & 0.497 \\
\hline Chemical \& Metal & 0.130 & -0.004 & 0.264 & 0.095 \\
\hline Textile \& Household & 0.089 & -0.180 & 0.199 & 0.059 \\
\hline Mining \& Quarrying & 0.157 & 0.005 & 0.225 & 0.233 \\
\hline Manufacturing & 0.164 & -0.001 & 0.341 & 0.304 \\
\hline Utilities & 0.243 & 0.074 & 0.432 & 0.480 \\
\hline Construction & 0.178 & 0.013 & 0.328 & 0.247 \\
\hline Trade & 0.110 & -0.103 & 0.215 & 0.219 \\
\hline Transport & 0.075 & -0.018 & 0.351 & 0.420 \\
\hline Banks \& Insurance & 0.300 & 0.151 & 0.383 & 0.510 \\
\hline Business Services & 0.267 & 0.097 & 0.409 & 0.535 \\
\hline Public Administration & -0.010 & -0.051 & 0.277 & 0.364 \\
\hline Education & -0.008 & -0.042 & 0.294 & 0.409 \\
\hline Health & 0.048 & -0.009 & 0.392 & 0.430 \\
\hline Other Services & 0.066 & 0.000 & 0.316 & 0.344 \\
\hline Firm empl.: 50-99 & 0.030 & 0.018 & 0.024 & -0.009 \\
\hline $100-499$ & 0.068 & 0.068 & 0.069 & 0.026 \\
\hline over 500 & 0.127 & 0.120 & 0.117 & 0.091 \\
\hline Constant & 3.847 & 3.814 & 3.831 & 3.277 \\
\hline
\end{tabular}




\section{IZA Discussion Papers}

\begin{tabular}{|c|c|c|c|c|}
\hline No. & Author(s) & Title & Area & Date \\
\hline 970 & $\begin{array}{l}\text { G. Kertesi } \\
\text { J. Köllõ }\end{array}$ & $\begin{array}{l}\text { Fighting "Low Equilibria" by Doubling the } \\
\text { Minimum Wage? Hungary's Experiment }\end{array}$ & 4 & $12 / 03$ \\
\hline 971 & $\begin{array}{l}\text { J. De Loecker } \\
\text { J. Konings }\end{array}$ & $\begin{array}{l}\text { Creative Destruction and Productivity Growth in } \\
\text { an Emerging Economy: Evidence from } \\
\text { Slovenian Manufacturing }\end{array}$ & 4 & $12 / 03$ \\
\hline 972 & J. Köllõ & $\begin{array}{l}\text { Transition on the Shop Floor - The Restructuring } \\
\text { of a Weaving Mill, Hungary 1988-97 }\end{array}$ & 4 & $12 / 03$ \\
\hline 973 & $\begin{array}{l}\text { C. Belzil } \\
\text { J. Hansen }\end{array}$ & $\begin{array}{l}\text { Structural Estimates of the Intergenerational } \\
\text { Education Correlation }\end{array}$ & 1 & $12 / 03$ \\
\hline 974 & $\begin{array}{l}\text { J. Schwarze } \\
\text { M. Härpfer }\end{array}$ & $\begin{array}{l}\text { Are People Inequality Averse, and Do They } \\
\text { Prefer Redistribution by the State? A Revised } \\
\text { Version }\end{array}$ & 3 & $12 / 03$ \\
\hline 975 & $\begin{array}{l}\text { A. Constant } \\
\text { K. F. Zimmermann }\end{array}$ & Occupational Choice across Generations & 1 & $12 / 03$ \\
\hline 976 & $\begin{array}{l}\text { J. D. Angrist } \\
\text { K. Lang }\end{array}$ & $\begin{array}{l}\text { Does School Integration Generate Peer Effects? } \\
\text { Evidence from Boston's Metco Program }\end{array}$ & 6 & $01 / 04$ \\
\hline 977 & $\begin{array}{l}\text { M. Corak } \\
\text { G. Lipps } \\
\text { J. Zhao }\end{array}$ & $\begin{array}{l}\text { Family Income and Participation in Post- } \\
\text { Secondary Education }\end{array}$ & 5 & $01 / 04$ \\
\hline 978 & $\begin{array}{l}\text { J. T. Addison } \\
\text { P. Portugal }\end{array}$ & $\begin{array}{l}\text { How Does the Unemployment Insurance System } \\
\text { Shape the Time Profile of Jobless Duration? }\end{array}$ & 3 & $01 / 04$ \\
\hline 979 & $\begin{array}{l}\text { M. Moreno } \\
\text { H. Ñopo } \\
\text { J. Saavedra } \\
\text { M. Torero }\end{array}$ & $\begin{array}{l}\text { Gender and Racial Discrimination in Hiring: A } \\
\text { Pseudo Audit Study for Three Selected } \\
\text { Occupations in Metropolitan Lima }\end{array}$ & 1 & $01 / 04$ \\
\hline 980 & $\begin{array}{l}\text { H. Ñopo } \\
\text { J. Saavedra } \\
\text { M. Torero }\end{array}$ & Ethnicity and Earnings in Urban Peru & 1 & $01 / 04$ \\
\hline 981 & H. Ñopo & Matching as a Tool to Decompose Wage Gaps & 1 & $01 / 04$ \\
\hline 982 & $\begin{array}{l}\text { I. Geishecker } \\
\text { H. Görg }\end{array}$ & $\begin{array}{l}\text { Winners and Losers: Fragmentation, Trade and } \\
\text { Wages Revisited }\end{array}$ & 2 & $01 / 04$ \\
\hline 983 & $\begin{array}{l}\text { D. Del Boca } \\
\text { M. Locatelli } \\
\text { D. Vuri }\end{array}$ & Child Care Choices by Italian Households & 3 & $01 / 04$ \\
\hline 984 & $\begin{array}{l}\text { W. Arulampalam } \\
\text { A. L. Booth } \\
\text { M. L. Bryan }\end{array}$ & $\begin{array}{l}\text { Are there Asymmetries in the Effects of Training } \\
\text { on the Conditional Male Wage Distribution? }\end{array}$ & 5 & $01 / 04$ \\
\hline 985 & $\begin{array}{l}\text { Š. Jurajda } \\
\text { H. Harmgart }\end{array}$ & When Are 'Female' Occupations Paying More? & 4 & $01 / 04$ \\
\hline
\end{tabular}

An updated list of IZA Discussion Papers is available on the center's homepage www.iza.org. 